\title{
NAPELEMES VILLAMOSENERGIA-TERMELŐ RENDSZEREK
}

\author{
Lipták Róbert \\ PhD hallgató, Miskolci Egyetem, Fizikai és Elektrotechnikai Intézet, \\ Elektrotechnikai és Elektronikai Intézeti Tanszék \\ 3515 Miskolc, Miskolc-Egyetemváros, e-mail: elkrobi@uni-miskolc.hu \\ Bodnár István \\ intézeti tanszékvezetö, egyetemi docens, Miskolci Egyetem, Fizikai és Elektrotechnikai Intézet, \\ Elektrotechnikai és Elektronikai Intézeti Tanszék \\ 3515 Miskolc, Miskolc-Egyetemváros, e-mail: vegybod@uni-miskolc.hu
}

\begin{abstract}
Absztrakt
Ez a cikk a napelemes rendszerek felépitését mutatja be. Az elsö részében az alapvetö épitö elemeit rendszerezi és mutatja be a napelem cellák föbb típusait, majd azt, hogy a napelem cellák miként alkotnak nagyobb egységeket és képezik a részét a napelemes rendszernek. A cikk második része a napelemes rendszerek felépitéséröl szól, illetve az alapvetö különbségeket mutatja be az önálló egységként müködö napelemes rendszerek, valamint a villamos hálózattal közvetlen vagy közvetett módon összekötött napelemes rendszerek között. Lényeges szempont lehet a jövöben a hálózatcsatolt energiatárolós $P V$ rendszer, továbbá a hibrid rendszerek, melyekkel hatékonyabban lehet hasznositani a megújuló energiaforrásokat.
\end{abstract}

Kulcsszavak: napelem, napelem cellák, napelemes rendszerek, PV rendszerek

\begin{abstract}
This article describes the structure of solar systems. In the first part, he systematizes the basic building blocks and presents the main types of solar cells, and then how the solar cells form larger units and form part of the solar system. The second part of the article is about the structure of the solar system, and shows the fundamental differences between solar systems in the self-contained unit as well as a direct or indirect way, the electric network connect on solar systems. An important aspect in the future may be the grid-connected energy storage PV system, as well as hybrid systems, which can be used more efficiently for renewable energy sources.
\end{abstract}

Keywords: solar cell, solar cell cells, solar systems, PV systems

\section{Bevezetés}

A kutatás-fejlesztés, az iparosítással együtt, napjainkban a fotovoltaikus lehetőségek széles portfóliójához vezetett, amelyek különböző fejlettségi szinteken állnak rendelkezésre. A napelemes alkalmazások széles választéka lehetővé teszi, a különféle technológiák megjelenését a piacon az alacsony költségü és alacsonyabb hatásfokú technológiáktól, egészen a magas hatékonyságú technológiákig, azonban ezek magasabb költségekkel járnak. A napelemes rendszerek magas beruházási költségeinek megtérülés ideje viszonylag hosszú, ez visszaveti népszerüségét a fosszilis alapú rendszerekkel szemben. Azonban a napenergia felhasználásával csökkenthető az energiatermelés környezeti terhelése, mindemellett számos elönyös tulajdonságokkal rendelkezik: 
- megújuló (emberi időléptékben képes megújulni),

- fenntartható (nem merül ki, nincs környezeti terhelés),

- tiszta (nem szennyezö),

- mindenütt jelen van (a Föld bármely pontján elérhetö).

A napenergia a legnagyobb mennyiségben jelenlévő megújuló energiaforrás, emellett költséghatékony, a szélenergia után az egyik legolcsóbb megújulóenergia-technológia. A napelemes rendszerek másik fontos előnye a moduláris tulajdonsága, amely lehetővé teszi egy nagyon rugalmas rendszer méretezését, az épületekbe történő integráláshoz és a decentralizált alkalmazásokhoz, minimális terheléssel. Általában nem tartalmaznak mozgó alkatrészeket, ezáltal nem termelődik súrlódásból adódó hő, illetve a kopás sem jellemző. Ennek köszönhetően a fotovoltaikus rendszerek csendesen müködnek, rendkívül magas megbízhatósággal, továbbá alacsony karbantartási igényt és hosszú élettartamot kínálnak. Az átalakítási folyamat jellegéből adódóan, a PV rendszer típusa szerint, közvetlenül alkalmazható diffúz sugárzás mellett, amely a mérsékelt éghajlaton nagyobb aránnyal alkalmazható [1].

A napelemes rendszerek fö hátránya, hogy szakaszos üzemü, tehát a müködése kiszámíthatatlan, valamint korlátozottan szabályozható. Jellemző a PV rendszerekre még az alacsony a teljesítménysürüsége, ami magas kezdeti beruházási költségekkel jár. Ezen kívül a napelem modulok hatásfoka viszonylag alacsony (14 és 25\% között), összehasonlítva más megújuló energia rendszerek hatásfokával [1].

\section{Napelemek}

Manapság a PV-cellák elsődleges elemei a félvezetők, bár a kutatók más anyagokkal is próbálkoznak, beleértve a szerves polimereket is. Alapvetően négy fő típusú PV-cella létezik, azaz a kristályos szilíciumnak két variációja, a monokristályos és a polikristályos, továbbá a vékonyréteg- és hibridcella [1].
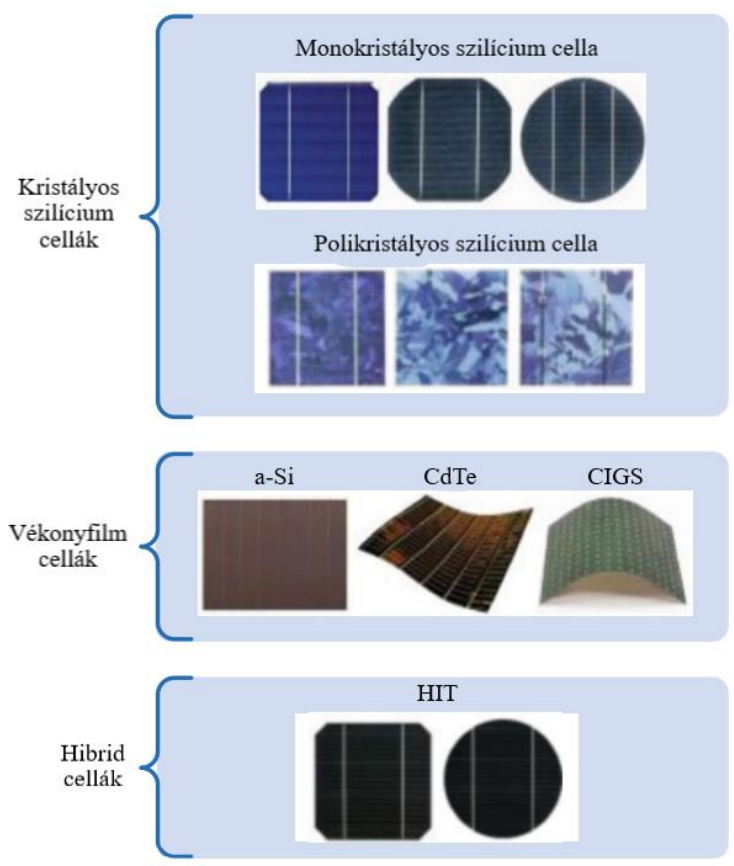

1. ábra. PV cellák alapvetö típusai [1] 


\subsection{Monokristályos napelem cellák}

A monokristályos (egykristályos) szilíciumot a Czochralski-eljárásból készült hengeres „tuskókból” vágják ki. A napelemeket álnégyzet alakúra vágják, hogy minimalizálják a feldolgozott monokristályos szilícium hulladékát. Ezért egy monokristályos szilíciumból előállított napelem modulban, a modul területének egy része nincs lefedve napelem cellával [5].

A teljes cella egy irányba van igazítva, ami azt jelenti, hogy amikor a nap ragyogóan süt rájuk, a megfelelő szögben, akkor rendkívül hatékonyak.

Egységesebb feketés színủek, mert elnyelik a fény nagy részét. A tiszta cellák nyolcszögletüek, bár vannak kerek és félig kerek cellák, így a sarkokban fel nem használt hely van, ha sok cellából készítenek napelem modult. A monokristályos cellák legfőbb előnye a nagy, körülbelül 18-20\% -os a hatásfok, bár a gyártási folyamat bonyolult és költséges [1]. Laboratóriumi körülmények között ez az érték akár $25-30 \%$ is lehet [4]. A tiszta szilícium ostya előállításának költsége valamivel több, mint a polikristályos celláké, de manapság nincs sok különbség az árban [1].

\subsection{Polikristályos napelem cellák}

Polikristályos vagy többkristályos szilíciumban a kristályszerkezet nem homogén eloszlású. A napelem cellák szemcsehatárokkal rendelkeznek. A gyártási folyamat során az olvadt szilíciumot grafittégelyekbe öntik, majd a hütést szabályozva kristályosítják ki. A kristályosodási folyamat a hütési folyamat közben több pontból indul meg [2]. Az ostyákat (kb. 180-350 $\mu \mathrm{m}$ vastagságúak) négyzet alakú rudakból vágják ki és komplett cellákká állítják össze [5].

A polikristályos napelemek olcsóbbak, mint a monokristályos napelemek, de ezeknek a napelemeknek alacsonyabb a hatékonyságuk a napelemekben jelenlévő szemcsehatárok miatt. Mivel az egyes kristályok nem feltétlenül tökétesen illeszkednek egymáshoz, mint a monokristályos cellák az előző esetben, így veszteségek vannak a cellák közötti rések miatt. Ez az eltérés azonban bizonyos körülmények között segíthet, mivel a cellák nem csak a megfelelő szögből megvilágítva tudnak müködni, hanem minden szögböl tudják a fényt hasznosítani, akár szórt fénynél vagy gyenge megvilágítás esetén is. A panelek megjelenése is más, a véletlenszerü kristályelrendezés miatt. A panelek kissé kékesebbek, mivel visszatükrözik a fény egy részét.

A polikristályos cellák korábban olcsóbbak voltak, mint a monokristályos cellák az egyszerübb gyártási folyamatuk miatt, de manapság áruk nagyon hasonlít a monokristályos cellákhoz, bár kissé alacsonyabb a hatásfokuk (kb. 14-18\%) [1]. Ez az érték laboratóriumi körülmények között 20\% [4].

\subsection{Vékonyfilm napelem cellák}

A vékonyfilm (egyes szakirodalmakban: amorf típusú) napelemek második generációs napelemek, amelyeket egy vagy több fázisban, vékony film réteget gőzölnek fel egy hordozóra, például üvegre, mủanyagra vagy fémre. A filmvastagság néhány nanométertől $(\mathrm{nm})$ a tízmikrométerig $(\mu \mathrm{m})$ változik. Így ez a fotovoltaikus anyagréteg sokkal vékonyabb, mint bármely más rivális technológia, például a kristályos szilícium napelem (c-Si), amely legfeljebb $200 \mu \mathrm{m}$-es ostyákat használ a c-Si-sejtek első generációjához. Ez az oka annak, hogy ,vékonyrétegü” PV napelem technológiának hívják őket. Ez a funkció lehetővé teszi, hogy a vékonyréteg-cellák rugalmasak, sokoldalúak, kisebb súlyúak legyenek. Jó teljesítményt nyújtanak közvetett fény és magas hőmérsékletủ alkalmazásokban egyaránt. A jellemzö hatékonyság körülbelül 6-12\%, de ezeket könnyebb és következésképpen olcsóbb elöállítani, mint a kristályos szilícium napelemeket [1]. 
Van azonban oka annak, hogy a vékonyrétegü napelem modulok még nem váltották ki a régebbi típusokat. A hatékonyságon kívül vannak olyan vékonyréteg-anyagok, amelyek teljesítményromlást mutattak az idő múlásával, stabilizált hatásfokuk 15-35\%-kal alacsonyabb, mint a kezdetben. A vékony fólia sokféle hordozóra rögzíthető, mind merev, mind rugalmas felületre egyaránt, így ideális ívelt és egyenetlen felületekhez is. Valamint üveg felületekre is felhordható. Három elterjedt vékonyréteg-napelem van a kereskedelemben, köztük az amorf vékonyréteg-szilícium (a-Si), amely még szilícium, de a kristályos celláktól eltérő formában, a kadmium-tellurid $(\mathrm{CdTe})$ és a réz-indium-gallium diSelenide (CIGS vagy egyszerüen CIS). Az amorf vékonyfilm szilícium hatásfoka 6-8\% közelében van, és elviseli az extrém meleget is, a szilícium-mentes CdTe és CIGS cellák nagyobb hatásfokkal, 9$11 \%$ és $10-12 \%$. Viszonylag kis mértékben befolyásolja a hőmérséklet ezt az értéket [1]. A legmagasabb laboratóriumi hatásfok a vékonyréteg technológiáknál: $21 \%$ a CdTe esetén és 20,5\% a CIGS napelemeknél. [4] Az egyéb vékonyréteg-technológiákat, amelyek még mindig a folyamatban lévő kutatások korai szakaszában vannak vagy korlátozott kereskedelmi hozzáférhetőséggel rendelkeznek, gyakran feltörekvő vagy harmadik generációs fotovoltaikus cellák közé sorolják. Ide tartoznak a szerves, a fényérzékeny festett cellák (dye-sensitised cells, DSC) és polimer napelemek, valamint a kvantumpont, a réz-cink ón-szulfid, a nanokristály, a mikromorf és a perovszkit napelemek. [1]

\subsection{Hibrid napelem cellák}

A negyedik típusú PV-elem olyan hibrid cellákból áll, amikor két különféle technológiát ötvöznek egy cellába: egy kristályos szilíciumcella, amely két réteg amorf „,vékony film” szilícium közé kerül. Egyes külföldi szakirodalmak HIT-heterojunction technológiának nevezik. Ezen technológia legfontosabb jellemzője, hogy az amorf emitter és a kristályos bázis közé egy vékony belső amorf szilíciumréteg kerül beillesztésre. A hatásfok akár a 19\%-ot is elérheti. A hibrid panelek azonban sokkal drágábbak, mint a mono- vagy polikristályos panelek, így a megtermelt energia növekedése még nem indokolja ennek a PV technológiának a többlet beruházási költségeit.

\section{Napelemes rendszerek felépítése}

A napelem cella, a napelemes rendszerek alapvető építő köve. A napelem mérete 0,5-0,6 DC közötti feszültséget produkál, méretétől függetlenül. A PV-cellák jelenlegi teljesítménye 2 és 5 amper között változik, a méret és a hatékonyság függvényében. A kimeneti teljesítmény szintén arányos a cellafelszínt érő napfény intenzitásával. Ez a legtöbb alkalmazáshoz nem elegendő teljesítmény. Következésképpen a cellákat modulokká (amelyet egyes szakirodalmak panelnek neveznek) egyesítik, jellemzően 36 cellával, hogy elérjék az 50-300 W-ot. A PV modulok sorba kötésével stringeket hoznak létre, azzal a céllal, hogy növeljék feszültségüket, a nagyobb feszültségü alkalmazások elérése érdekében. Végül a stringeket sorosan/párhuzamosan, alacsony/nagy feszültség mellett kombinálva akár több tíz MW (vagy annál is nagyobb) PV rendszer képezhető [1,3]. Ezt mutatja a Hiba! A hivatkozási forrás nem található.2. ábra.

\section{1. Önálló (szigetüzemü) napelemes rendszerek}

Az önálló PV rendszerek autonóm rendszerek, amelyek a közüzemi hálózattól függetlenül müködnek. Az önálló napelemes rendszerek „Off-grid rendszerek” vagy szigetüzemü néven is ismertek, mivel nem csatlakoznak a hálózathoz. Az önálló napelemes rendszerek két kategóriába sorolhatók:

- közvetlen-csatolású önálló napelemes rendszerek és

- akkumulátortárolós önálló napelemes rendszerek [4]. 


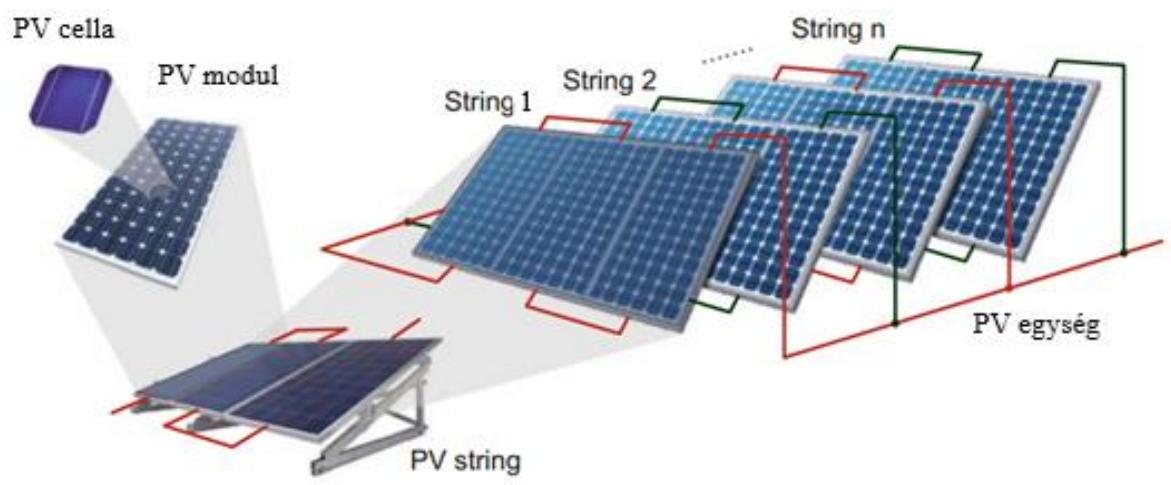

2. ábra. A PV cellák és nagyobb egységei [1]

\subsubsection{Közvetlen-csatolású napelemes rendszerek}

A közvetlen összekapcsolt szigetüzemű napelemes rendszer PV panelekből és fogyasztóból állnak. Ez a 3. ábrán látható. A napelemek villamos energiát termelnek és egyenáramú fogyasztókat látnak el. Közvetlenül összekapcsolt rendszer nincs csatlakoztatva semmilyen akkumulátorhoz vagy hálózathoz. A rendszer egy vagy több napelemet tartalmaz, továbbá leválasztó kapcsolót, túláramvédelmet, illetve az elektromos fogyasztót.

Ezek a rendszerek voltak az uralkodó PV rendszerek, mielött a hálózat csatolt rendszerek az utóbbi években egyre népszerúbbé váltak. Az önálló fotovillamos rendszerek egyik legnagyobb előnye, hogy a rendszer kimeneti teljesítménye a mikrowattól a megawattig terjed, amelyeket különböző területeken alkalmaznak például órák, számológépek, ventilátorok, vízszivattyúzás, távoli kommunikáció, műholdak, ürjármüvek és megawatt méretü erőmüvek. Bizonyos terheléseknél, például a pozitív térfogatú vízszivattyúknál, a PV egység és a terhelés között egyfajta elektronikus DC - DC átalakítót, úgynevezett maximális munkapont-követőt vagy töltésszabályozót használnak, hogy jobban kihasználják a rendelkezésre álló PV egység maximális teljesítményét (4. ábra) [3].

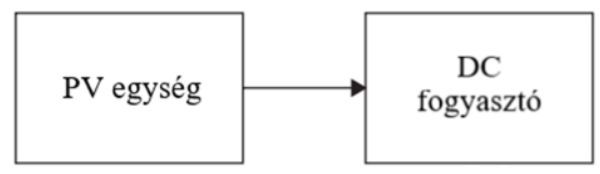

3. ábra. Közvetlen-összekapcsolt szigetüzemü PV-rendszer blokkvázlata [3]

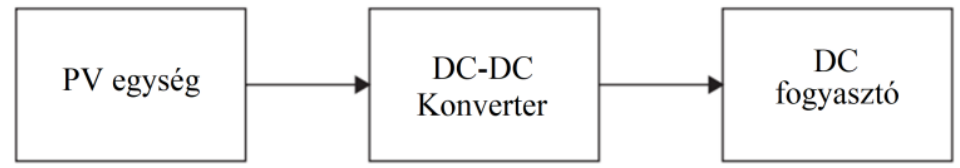

4. ábra. Közvetlen-összekapcsolt szigetüzemü PV-rendszer blokkvázlata DC-DC szabályzóval [3] 


\subsubsection{Akkumulátortárolós önálló napelemes rendszerek}

A közvetlen összekapcsolt rendszerek egyik hátránya, hogy képtelenek éjszakai vagy felhős napokon, elégtelen megvilágítás mellett müködni. Ezt a hátrányt kiküszöbölhetjük egy akkumulátoros tárolóval ellátott PV rendszer használatával (5. ábra).

A villamos energia fogyasztási igénye ritkán egyezik meg a PV panel kapacitásával. Előnye, hogy tárolja az energiát, amely szükség esetén biztosítja azt. Továbbá a tranziensek kiküszöbölésével stabil áramot és feszültséget biztosít [3].

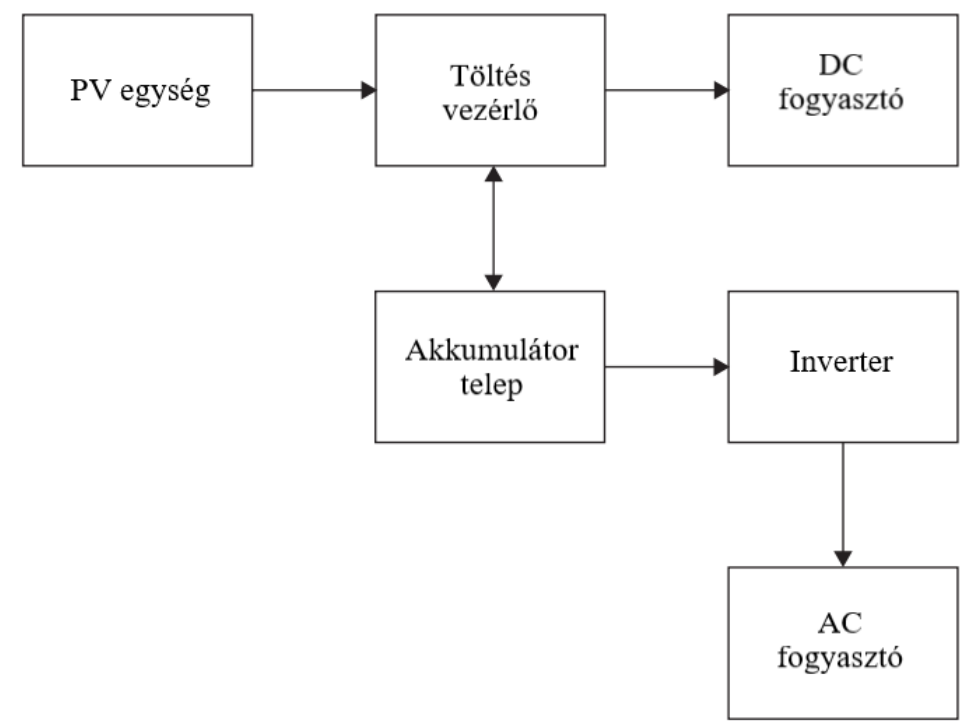

5. ábra. Az akkumulátoros önálló rendszer blokkvázlata [3]

\subsection{Hálózatcsatolt rendszer}

A másik nagy felhasználási lehetősége a PV rendszereknek, az önálló napelemes rendszerek mellett, a hálózatcsatolt rendszerek. Külföldi szakirodalmakban „Grid-connected solar system” vagy „Grid-tied solar system" néven szerepelnek. A hálózatcsatolt napelemes rendszereknek az alapvető tulajdonsága az, hogy közvetlen vagy közvetett (pl.: vezérlőn keresztül) módon csatlakoztatva vannak a közcélú villamos hálózathoz. Számos kialakítás megvalósítható attól függően, hogy a rendszer milyen rendszerelemeket tartalmaz.

1. A hálózatra közvetlenül visszatápláló PV rendszer

2. Hálózat-interaktív szigetüzemü PV rendszer

3. Hálózatcsatolt energiatároló PV rendszer

\subsubsection{A hálózatra közvetlenül visszatápláló PV rendszer}

A hálózatra visszatápláló rendszereknél az összes megtermelt villamos energia mérésre kerül az áramszolgáltató által felszerelt hitelesített mérővel. A rendszer a következő elemekből épül fel (6. ábra):

- Napelem (PV) modulok

- DC oldali energiatovábbítás és védelem

- Inverter (egyenáram (DC) átalakítása váltóáramra (AC))

- Létesítmény fogyasztói

- Áramszolgáltatói fogyasztásmérés "ad-vesz" mérővel 
- -AC oldali védelmi készülékek

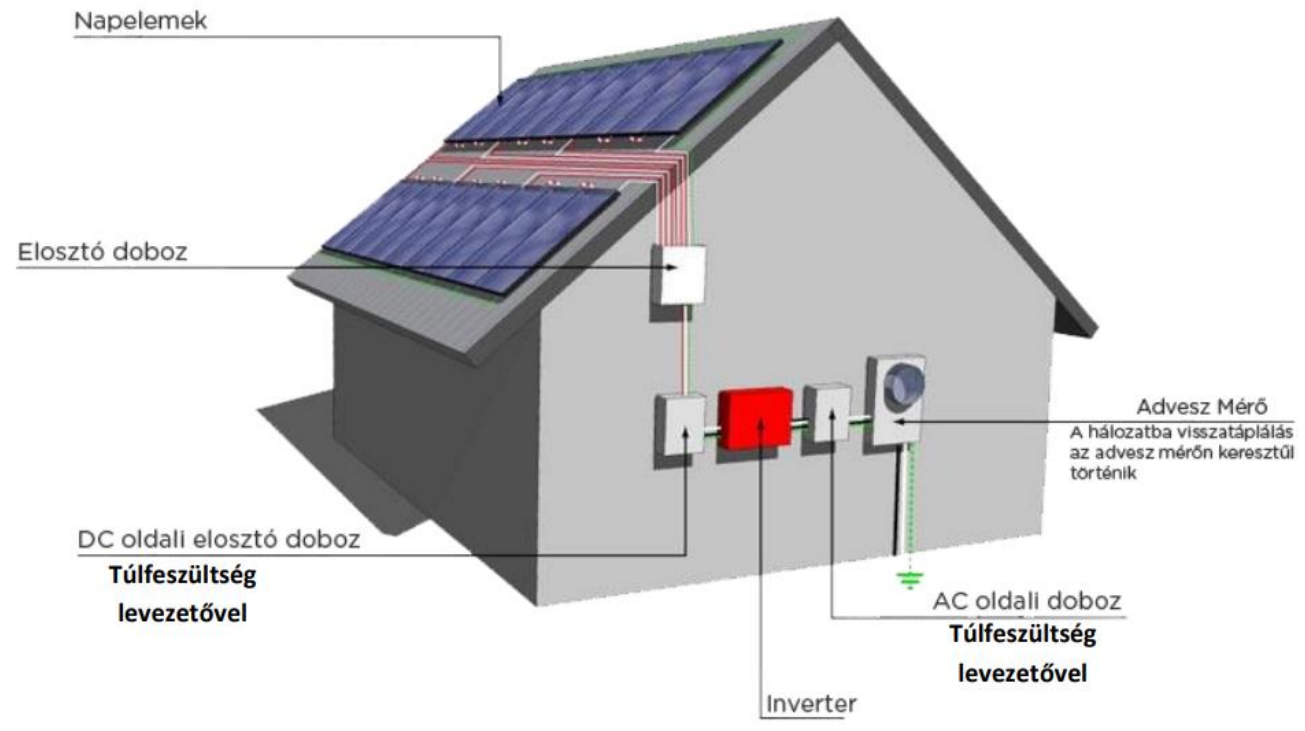

6. ábra. A hálózatra közvetlenül visszatápláló PV rendszer [2]

A napelemes rendszerrel megtermelt villamos energia az inverteren keresztül közvetlenül felhasználásra kerülhet. Amennyiben a létesítmény fogyasztói mégsem használják fel a megtermelt villamos energiát, akkor az Áramszolgáltatói "ad-vesz" mérőn keresztül visszatáplálásra kerül a közcélú hálózatba.

Azokban az időszakokban, amikor a PV rendszer nem termel, de a fogyasztóknak villamos energiára van szükségük, akkor a szükséges energiát a közcélú hálózatból vételezi a rendszer [2].

A rendszer védelmi elemeit tekintve a 7. ábra részletesen bemutatja mind egyenáramú, és mind váltakozó áramú oldalon is.

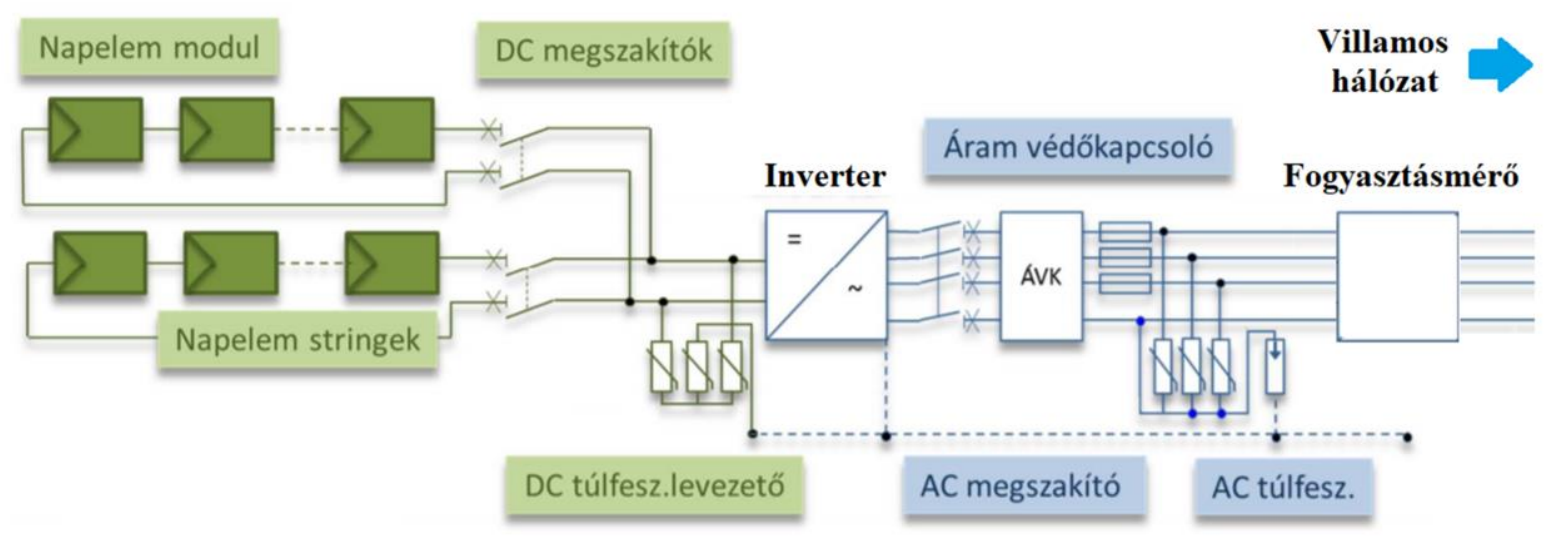

7. ábra. A hálózatra közvetlenül visszatápláló PV rendszer védelmi elemei [7] 


\subsubsection{Hálózat-interaktív szigetüzemü PV rendszer}

Ezen rendszereknek közvetett kapcsolata van a közcélú villamos hálózattal. Felépítésüket tekintve tartalmaznak minden olyan elemet, amely az önálló (szigetüzemü), valamint a hálózatra közvetlenül visszatápláló PV rendszerek tartalmaznak:

- Napelem (PV) modulok

- DC oldali energiatovábbítás és védelem

- Töltésvezérlö

- Akkumulátor telep

- Inverter (egyenáram (DC) átalakítása váltóáramra (AC))

- Létesítmény fogyasztói

- Áramszolgáltatói fogyasztásmérés “ad-vesz” mérővel

- AC oldali védelmi készülékek

Továbbá ezen rendszerelemeken kívül még tartalmaz egy terhelés-átkapcsolót is, amely müködését tekintve a hálózati fogyasztókat a napenergia rendelkezésre állásakor az inverter kimenetére kapcsolja, ellenkező esetben pedig a hálózatra. Ezt Hálózat-interaktív szigetüzemü PV rendszernek nevezzük [2].

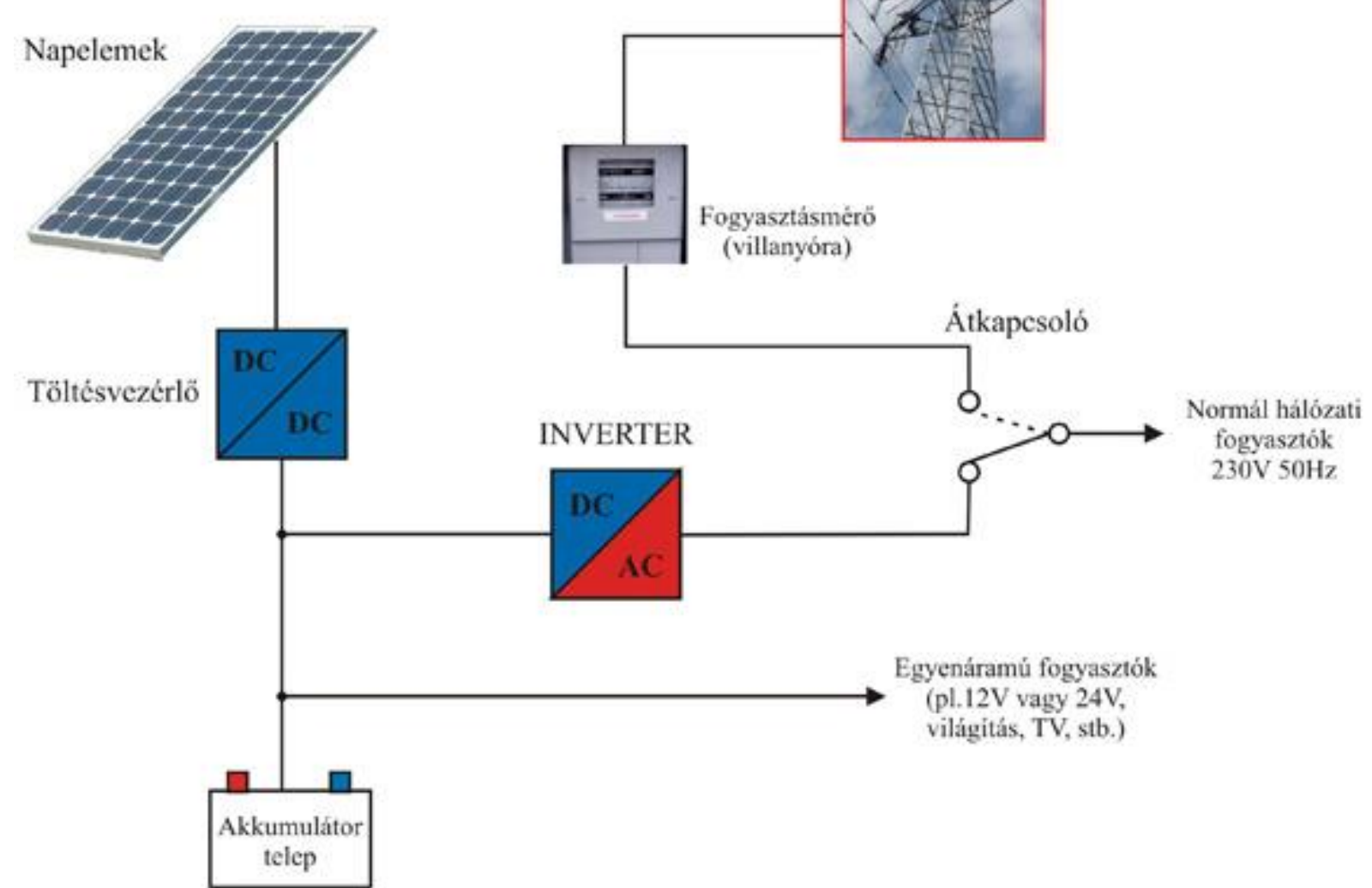

8. ábra. Hálózat-interaktív szigetüzemü PV rendszer [2] 


\subsubsection{Hálózatcsatolt energiatároló $P V$ rendszer}

Az előző rendszernek a hiányossága abból adódott, hogy egy időben nem állt rendelkezésre az összes funkció, amelyet a rendszer biztosítani tudna. A hálózatcsatolt energiatároló PV rendszer sajátossága, hogy a váltakozó áramú bemeneti és kimeneti oldal, valamint az egyenáramú bemeneti és kimeneti oldal egy központi töltésvezérlőre kapcsolódik és a fogyasztók felé aszerint történik az energia elosztása, hogy milyen energiaforrás áll rendelkezésre. Egy lehetséges rendszerfelépítést mutat a 9. ábra.

Elsődlegesen az akkumulátor telepet tölti a napelemes rendszer, illetve táplálja a fogyasztókat. A többlet energiát, amit termel, azt a közcélú hálózatba táplálja vissza. Az akkumulátor telepek teljesen fel vannak töltve, amíg a hálózati feszültség jelen van. Hálózat kimaradáskor az energiavételezés az akkumulátorokból történik. Részletesebb blokkvázlatot mutat a 10. ábra.

A hálózati feszültséget egy EIR/INV egyenirányító/inverter modul alakítja át egy közbensőköri DC+/- 400V-os feszültségre. Ebből vételezzük és tápláljuk be az energiát, úgy, hogy az energiaegyensúly mindig létre tudjon jönni. A napenergia csak abban az esetben hasznosul maximálisan, ha a közbensőköri energiaegyensúly folyamatosan fennáll. Ha az akkumulátorok feltöltött állapotban vannak és a fogyasztók nem vételeznek villamos energiát, akkor a napelem az EIR/INV modulon keresztül a hálózatba visszatáplálja az energiát. A rendszer célja az, hogy az akkumulátorokban minél több megtermelt megújuló energiát tároljon, valamint a lehető legkevesebb energiát vételezzen a közcélú hálózatból [6].

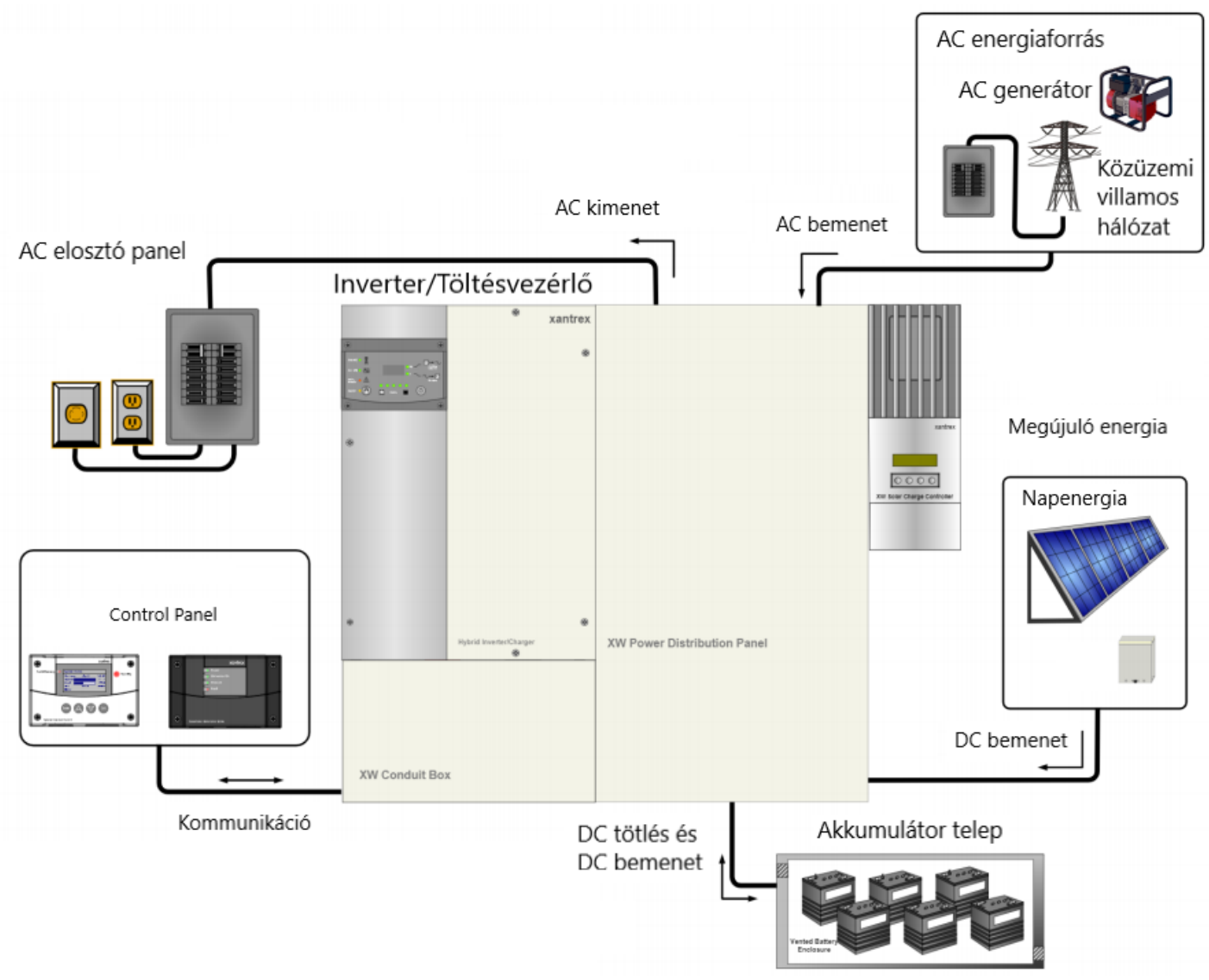

9. ábra. Hálózatcsatolt energiatárolós PV rendszer [8] 


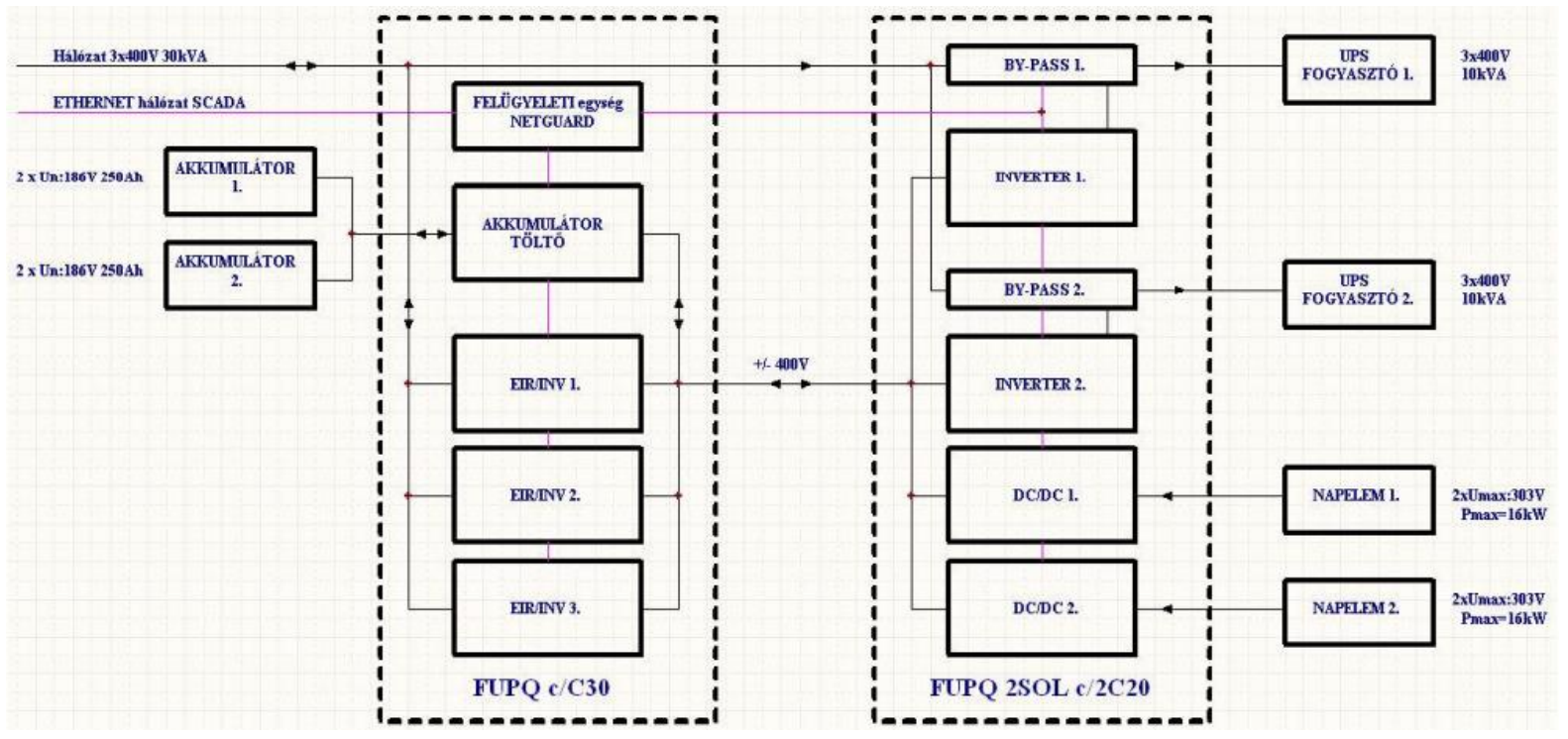

10. ábra. Hálózatcsatolt energiatárolós PV rendszer blokkvázlat [6]

\section{4. Összefoglalás}

Az talán eddig sem volt kérdés, hogy a napelemes rendszerek által a villamosenergia-termelés tisztábbá tehető, valamint a fenntarthatósága hosszútávon növelhető. Ha a napelemes rendszert, amely hálózattal van összekötve, kiegészítjük akkumulátor teleppel és a rendszer irányítását úgy alakítják ki, hogy az akkumulátorokban minél több megtermelt megújuló energia tárolódjon, azzal még inkább hatékonnyá lehet tenni a rendszert. Ezek a rendszerek tovább is kombinálhatók más megújuló energia hasznosító berendezésekkel, amely lehetővé teszi a hibrid rendszerek használatát.

\section{Irodalom}

[1] Zambroni de Souza, A. C., Castilla, M.: Microgrids design and implementation, Springer Nature Switzerland AG 2019. https://doi.org/10.1007/978-3-319-98687-6

[2] Bodnár, I.: Napelem müködésének alapjai, a napelemes villamosenergia termelés elmélete és gyakrolati megvalósitása, Miskolc, 2019, ISBN 978-615-00-4566-5

[3] Qazi, S.: Standalone photovoltaic (PV) systems for disaster relief and remote areas, 2017, ISBN: 978-0-12-803022-6 https://doi.org/10.1016/B978-0-12-803022-6.00005-8

[4] Kaushika, N. D., Mishra, A., Rai, A. K.: Solar photovoltaics technology, system design, reliability and viability, India, 2018, ISBN 978-3-319-72403-4

[5] Tiwari, G. N., Tiwari, A., Shyam: Handbook of solar energy theory, analysis and applications, Singapore 2016. (eBook) https://doi.org/10.1007/978-981-10-0807-8

[6] Dohány, L., Várhelyi, N.: 3 KVA-es és 30 KVA-es Napelemes energiatároló rendszerek Fóton, Villamosmérnöki Tudományok, I. évf. 2. szám (2018) pp. 69-76. ISSN 2560-2713

[7] Mészáros, L., Schottner, K.: Megújuló energiatermelö rendszerek Napelemes erömüvek, Magyar Mérnöki Kamara Elektrotechnikai Tagozat, 2015. február

[8] https://studylib.net/doc/18135452/xw-power-system-installation 